\title{
Heavy Metal Concentrations in Water Samples from Lake Kivu, Rwanda
}

\author{
Antoine Nsabimana $^{1 *}$, Valens Habimana ${ }^{2}$ and Gaidashova Svetlana ${ }^{3}$ \\ ${ }^{1}$ Department of Biology, School of Science, College of Science and Technology, University of Rwanda; P.O. Box: \\ 3900 Kigali, Rwanda. Tel: +250788435561 \\ ${ }^{2}$ Department of Chemistry, School of Science, College of Science and Technology, University of Rwanda; P.O Box: \\ 3900 Kigali, Rwanda. \\ ${ }^{3}$ Rwanda Agriculture and Animal Resources Development Board, P.O Box: 5016 Kigali, Rwanda. \\ *Corresponding author: Antoine Nsabimana, Email antoine.nsabimana@gmail.com
}

\begin{abstract}
Heavy metals are among the pollutants threatening the living organisms including human beings. The presence of heavy metals in water is of great concern due to their toxicity to aquatic organisms, humans and ability to accumulate in food chains. Thus, there is a need to regularly monitor heavy metal levels in aquatic medium. The present study was conducted to assess heavy metal concentrations in Lake Kivu water. Water samples from Lake Kivu were taken from three sites, namely: Rusizi, Karongi and Rubavu. Heavy metals in the samples were analyzed using Atomic Absorption spectro-photometer (SHIMADZU AAS-6800) and Inductively Coupled Plasma Optical Emission Spectroscopy (ICP-OES).Copper, lead, cadmium, chromium, manganese, mercury and arsenic concentrations were determined. Copper ranged from 3.24 to $10.01 \mu \mathrm{g} / \mathrm{l}$, lead varied from 8.81 to $37.44 \mu \mathrm{g} / \mathrm{l}$, cadmium ranged from 5.01 to 14.01 $\mu \mathrm{g} / \mathrm{l}$,chromium was between 139.5 and $226.6 \mu \mathrm{g} / \mathrm{l}$, manganese varied from 598.3 to $795.7 \mu \mathrm{g} / \mathrm{l}$, mercury ranged from 0 to $0.047 \mu \mathrm{g} / \mathrm{l}$, while arsenic was not detected in any of the analyzed water samples. Except for arsenic, all the other heavy metals exceeded the EPA (US Environment Protection Agency) maximum permissible limit for class III surface water intended for fish consumption and recreation. Thus, there is a need to establish the sources of lake water pollution by heavy metals in order to design further strategies limiting the amounts of heavy metals entering Lake Kivu.
\end{abstract}

Keywords: Cadmium, chromium, copper, lead, manganese, mercury 


\section{INTRODUCTION}

Lake Kivu is situated at 1,463 m altitude and maximum depth of $485 \mathrm{~m}$ in the Western part of the East African Rift zone between Rwanda and Democratic Republic of Congo. An estimated two million people use Lake Kivu water for drinking water without any treatment (Olapade and Omitoyin, 2012). The lake has accumulated a huge amount of methane and carbon dioxide(Schmid and Wüest, 2012; Bärenbold et al., 2020), and itis characterized by significant nutrient inflow from soil runoff from surrounding steep slopes (Muvundja et al.,2009). Lake Kivu is also located in a volcanic region and surrounded with active volcanoes (Nyamuragira and Nyiragongo). The active volcanoes may contaminate the lake with mercury and other heavy metals (Bagnato et al., 2015).

Heavy metals are chemical elements with a density greater than $5 \mathrm{~g} / \mathrm{cm}^{3}$ (Al-najjar et al., 2016.) They are also called trace elements as they are found in biological systems in low concentrations (Al-najjar et al., 2016). Heavy metals can be present naturally in aquatic environment (Sani,2011), however, anthropogenic activities marking the recent development such as modern agriculture, industrialization, construction and mining have contributed to the increase of heavy metals and other pollutants in different environments(Mensoor and Said, 2018).Heavy metals are persistent in the environment as they are not eliminated by biodegradation or chemical processes (Ashraf et al., 2012). Lead, cadmium, arsenic and mercury have no biological role in the metabolism of human being and aquatic organisms and are very toxic (Shah, 2017). Apart from toxic heavy metals, other metals can be classified as essential. Copper, manganese and chromium are essential for the metabolism of living organisms including human being; however, they are toxic if present at high quantities (Aliyu et al., 2015).

Assessing the level of heavy metals in lake could be an important aspect of environmental protection and a tool that influences the policy makers in decision making on environmental issues. Among the sources of heavy metals presence in the lake could be the discharge of untreated effluents from various sources into the lake (Thangamalathi and Anuradha, 2018), and soil erosion. The erosion, landslides and seismicity result in the transport of the neighboring soil into the lake and may contain heavy metals (Bagalwa et al., 2015). Limited studies have been conducted on water pollution in Lake Kivu, while major research attention was focused on methane gas resources (Bärenboldet al., 2020; Roland et al.,2017; Wüest et al., 2012, Pasche et al., 2011; Jannasch, 1975; Deuser et al., 1973).However, recent urban growth of cities located on lake borders, limited soil protection and expansion of open mining sites in the lake zone might pose risks for increased water pollution in the lake. Therefore, the present study aimed to assess the concentrations of heavy metals in water in major fishing sites of the Rwandan part of Lake Kivu. 


\section{METHODS}

Water samples were taken in Northern, Easternand Southernparts of Lake Kivu, which represent the major fishing sites near the settlements/cities - Rubavu, Karongi and Rusizi, respectively (Fig. 1). Thecoordinates were taken for water stations at Rusizi (28.89341, -2.48202); Rubavu (29.25512, -1.73278) and Karongi (29.31138, -2.06042) using GPS Garmin 60. Water samples were taken at surface and $40 \mathrm{~m}$ depth using a NISKIN bottle, repeated three times, on which an RBR 620 CTD (Conductivity, Temperature and Depth) probe was attached to record the depth and physical properties of the water. Samples were transported in a cool box to the laboratory and stored at $4^{\circ} \mathrm{C}$. A Method 3005, which is an acid digestion procedure, was used to prepare water samples for analysis by Inductively Coupled Plasma Optical Emission Spectroscopy (ICPOES). Water samples were acidified at the time of collection with $\mathrm{HNO}_{3}(5 \mathrm{~mL} / \mathrm{L})$.

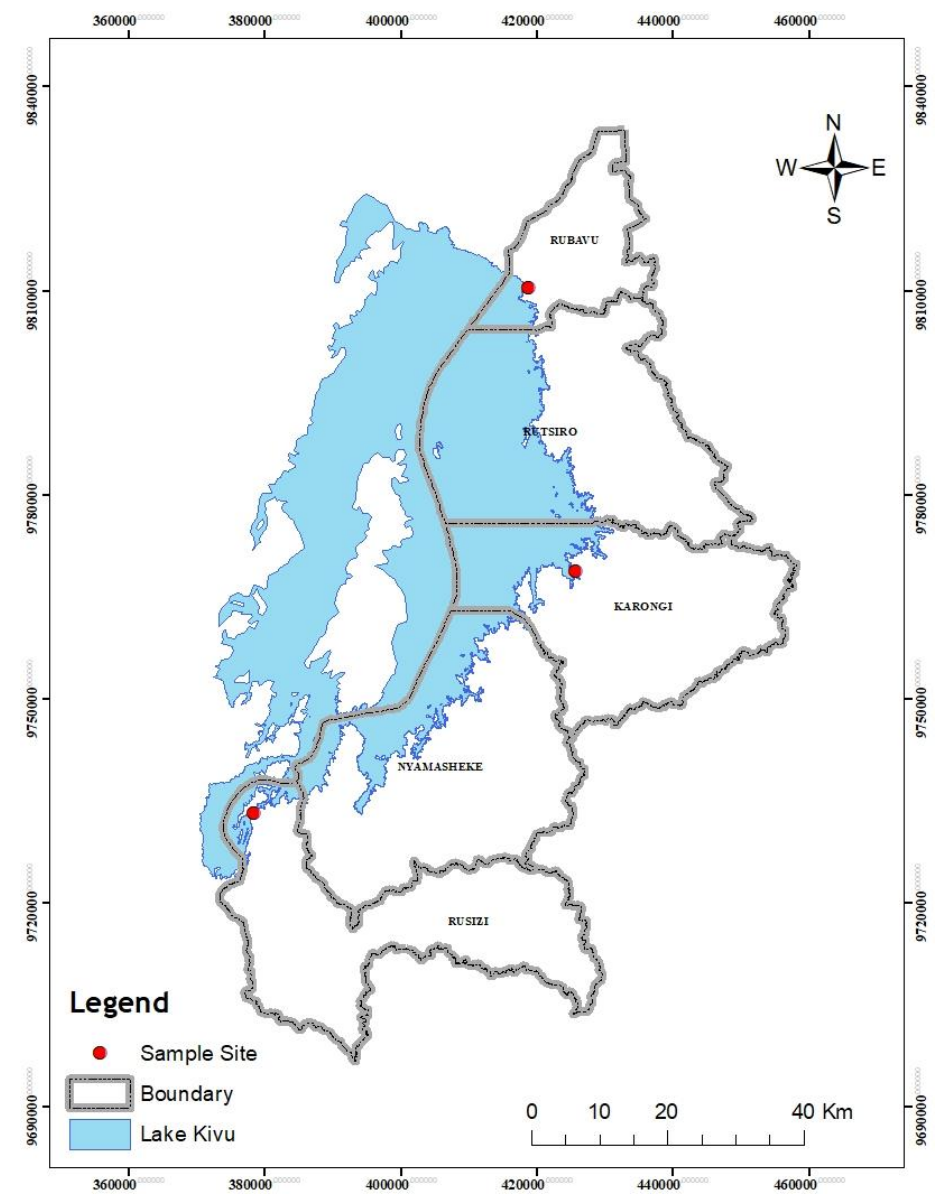

Fig.1 Map showing the sampling points on Lake Kivu (The map was prepared using ArcGIS version 10.6) 
At the time of analysis, the water samples were heated with acid and substantially reduced in volume. The obtained volume was filtered and diluted. A 100-mL aliquot of well-mixed sample was transferred to a beaker and $2 \mathrm{~mL}$ of concentrated $\mathrm{HNO}_{3}$ and $5 \mathrm{~mL}$ of concentrated $\mathrm{HCl}$ were added. Each sample was covered with a ribbed watch glass and heated on a hot plate at $90{ }^{\circ} \mathrm{C}$ until the volume has been reduced to $15 \mathrm{ml}$. The beaker was then removed from the hot plate and allowed to cool, washed with water and sample filtered to remove silicates and other insoluble material that could clog the nebulizer. Thereafter, the volume was adjusted to $100 \mathrm{ml}$ with reagent water.

The observed heavy metal concentrations were compared with the available maximum permissible limits for heavy metals from the US Environment Protection Agency for surface water intended for fish consumption, recreation, propagation and maintenance of a healthy, well balanced population of fish and wildlife (EPA, 2018).

\section{RESULTS}

The concentrations of most of the heavy metals analyzed in water samples from Lake Kivu exceeded the US Environment Protection Agency (EPA) maximum permissible limitintended for fish consumption, recreation, propagation and maintenance of a healthy, well-balanced population of fish and wildlife across all sites and both depths: at water surface and at 40m depth (Table 1). The concentration of lead in water samples varied from $11.02 \mu \mathrm{g} / \mathrm{l}$ to $35.24 \mu \mathrm{g} / \mathrm{l}$, which exceeded up to 3 or 4 times the EPA maximum permissible limit of $8.5 \mu \mathrm{g} / \mathrm{l}$. This was consistent at both, surface water and 40m depth and all sites (Table 1). Cadmium ranged from 6.01 to 12.51 $\mu \mathrm{g} / \mathrm{l}$. Cadmium concentration exceeded EPA maximum permissible limit of $8.8 \mu \mathrm{g} / \mathrm{l}$ in three samples out of six in Rubavu and one sample out of six in Rusizi, while its concentration was below $8.8 \mu \mathrm{g} / \mathrm{l}$ in Karongi (Table 1).

Table 1. Heavy metals concentrations $(\mu \mathrm{g} / \mathrm{l})$ in water samples from Lake Kivu (water depths at 0 and 40m)

\begin{tabular}{ccccccccc}
\hline Depth (m) Replicate & $\mathbf{P b}$ & $\mathbf{C d}$ & $\mathbf{C u}$ & $\mathbf{C r}$ & Mn & As & Hg \\
\hline \multicolumn{8}{c}{ Location: Rusizi } \\
\hline 0 & 1 & 35.24 & 12.51 & 7.28 & 203.13 & 751.07 & ND & 0.015 \\
0 & 2 & 24.23 & 6.01 & 8.65 & 191.41 & 781.70 & ND & 0.0055 \\
0 & 3 & 25.33 & 8.01 & 5.01 & 207.04 & 687.23 & ND & 0.026 \\
40 & 1 & 25.33 & 7.51 & 6.83 & 183.60 & 683.40 & ND & 0.0135 \\
40 & 2 & 33.04 & 6.01 & 9.56 & 214.85 & 683.83 & ND & 0.0085 \\
40 & 3 & 11.02 & 9.51 & 7.23 & 218.75 & 653.19 & ND & 0.018 \\
\hline \multicolumn{7}{c}{ Location: Karongi } \\
\hline 0 & 1 & 28.85 & 8.40 & 4.03 & 151.40 & 738.59 & ND & ND \\
0 & 2 & 30.93 & 7.39 & 3.45 & 153.19 & 628.54 & ND & 0.0028 \\
0 & 3 & 25.63 & 6.80 & 5.83 & 176.95 & 675.10 & ND & 0.0008
\end{tabular}


https://doi.org/10.4314/rjeste.v3i2.3

\begin{tabular}{ccccccccr}
\hline 40 & 1 & 25.98 & 6.59 & 5.06 & 166.82 & 751.20 & ND & ND \\
40 & 2 & 27.33 & 7.15 & 4.83 & 141.18 & 615.38 & ND & 0.0021 \\
40 & 3 & 27.67 & 8.23 & 4.75 & 151.96 & 684.09 & ND & ND \\
\hline \multicolumn{7}{c}{ Location: Rubavu } \\
\hline 0 & 1 & 23.42 & 10.67 & 5.94 & 193.41 & 620.52 & ND & 0.0335 \\
0 & 2 & 30.71 & 7.92 & 7.20 & 149.13 & 600.37 & ND & 0.030 \\
0 & 3 & 27.33 & 10.56 & 7.16 & 186.92 & 614.01 & ND & 0.021 \\
40 & 1 & 19.56 & 11.37 & 5.71 & 160.33 & 638.98 & ND & 0.027 \\
40 & 2 & 23.37 & 8.65 & 8.35 & 164.63 & 609.87 & ND & 0.046 \\
40 & 3 & 22.00 & 7.89 & 8.68 & 171.75 & 620.39 & ND & 0.0125 \\
\hline & & & & & & & & \\
MPL* & & 8.5 & 8.8 & 3.7 & 50 & NR & 0.025
\end{tabular}

* MPL - Maximum Permissible Limit set by the United States Environmental Protection Agency for Class III surface water intended for fish consumption, recreation, propagation and maintenance of a healthy population of fish and wildlife (EPA, 2018). ND: Not Detected; NR - Not Regulated.

Copper in water samples ranged from 3.45 to $9.56 \mu \mathrm{g} / \mathrm{l}$, which exceeded the EPA maximum permissible limit of $3.7 \mu \mathrm{g} / \mathrm{l}$ up to 2 times in all sites and both depth, except one sample out of 6 at Karongi where it was below the EPA maximum. Chromium concentration in water samples was between $141.2 \mu \mathrm{g} / \mathrm{l}$ and $218.8 \mu \mathrm{g} / \mathrm{l}$, which was 3-4 times higher than the EPA maximum permissible concentration of $50 \mu \mathrm{g} / \mathrm{l}$. This was in all sites and both, surface water and $40 \mathrm{~m}$ depth. Manganese concentration varied from $609.9 \mu \mathrm{g} / \mathrm{l}$ to $781.7 \mu \mathrm{g} / \mathrm{l}$. This was higher than for any other heavy metal, however, no EPA maximum permissible limits were recommended for chromium. Arsenic was not detected in any of the samples, while mercury concentration ranged from 0 to $0.046 \mu \mathrm{g} / \mathrm{l}$.One sample out of six in Rusizi, and four out of six in Rubavu exceeded the EPA maximum permissible limits for mercury, which was $0.025 \mu \mathrm{g} / \mathrm{l}$ (Table 1). In Karongi site, mercury was not detected in three samples out of six, and it was present at low concentrations not exceeding the EPA limits in the remaining three samples.

\section{DISCUSSION}

In the whole East African region, lakes constitute an important source of fishing for surrounding population, while water pollution may threat human health. Contamination of water and fish resources by heavy metals and pesticides was the subject of recent research: for the lakes Victoria (Ogwok et al., 2009; Nakuru (Mavura and Wangila, 2003); Ethiopian lakes Koka and Awassa (Dsikowitzky et al., 2013); Rwandan lakes Muhazi (Mupenzi et al., 2009) and South Cyohoha (Bazimenyera et al., 2014), where contamination of water and fish by different heavy metals was described. Yabe et al. (2010) review described water and fish contamination by heavy metals as pertinent but scarcely studied problem for the whole Africa.

Among the factors contributing to increased presence of heavy metals in water, the following were described: anthropogenic activities around the lake (Aderinola et al., 2009), mining, industrial waste water, municipal waste water and agricultural activities (Aprile and Bouvy, 
2010), mineral composition of underlying rock and soil around the surface water (Shehu et al., 2015).

Excess concentration of heavy metals in surface water has an effect on both, water organisms and human beings (He et al., 2018). It is possible that heavy metals in water bodies could have an effect on primary productivity in aquatic ecosystem (Jamal et al., 2013).Copper, Manganese and Chromium are essential for the metabolism of living organisms including human being, they are toxic at high level (Olapade and Omitoyin, 2012) causing anemia in fish, kidney and liver damage in human being (Thangam et al., 2014). Excessive manganese may cause brain damage in invertebrates (Baden and Eriksson, 2006). Chromium in aquatic environment is derived from a discharge of waste from metallurgical, electroplating, paints, pigments, tanning, wood, chemicals and paper industries (Saha et al., 2011).

Lead, Cadmium, Arsenic and Mercury have no biological role and are very toxicto both, human beingand aquatic organisms (Shah, 2017). Lead is very toxic and accumulates in aquatic food chains (Afshan et al., 2014). High level of cadmium in water can decrease egg production thereby reducing the offspring's which results in a population decline and thus leading to low productivity (Cherif et al., 2015). The sources of cadmium and lead in water include the use of phosphate fertilizers, discharging waste water from the industries producing alloys, pigments and batteries (Tchounwou et al., 2012). Other sources of lead include metal plating, waste from battery industries, exhaust from automobiles, smelting of ores and factory chimneys (Jaishankar et al., 2014). Mercury may be originated from the erosion of the upland soil (Obrist et al., 2018), the discharge of waste and chemical production facilities (Pacyna et al., 2009), volcanic eruptions and emissions (Hansell et al., 2006), mining (Wang et al., 2004).

Although Lake Kivu and surrounding areas are known by the lack of big industries and most of human activities are related to agro-pastoral occupation and fisheries, the main findings of our study reveal wide contamination of surface and deep water in Lake Kivu by a range of heavy metals. Thus, it is the first report for Lake Kivu. Although our study was not based on extensive sampling as it was exploratory, the fact that the range of heavy metals in the collected water samples exceeded the US EPA maximum permissible levels by 2-4 times across all three sites and at both, surface water and $40 \mathrm{~m}$ depth would be the indicator that the contamination of water by heavy metals may be widespread. Further studies are needed definitely: (i) with more extensive sampling to investigate the pertinence of the problem; (ii) to develop health standards with recommendations limiting drinking of water from the lake and (iii) to conduct further research to establish contamination levels by heavy metals in fish. The last is particularly important with the recent expansion of cage farming (Kampayana et al., 2016; RAB, 2018).

\section{CONCLUSION}

The results from the conducted assessment of heavy metals in Lake Kivu revealed that the concentration of Copper, Lead, Cadmium, Chromium, Manganese and Mercury in water were above the EPA maximum permissible limit for surface waterintended for fish consumption, 
recreation, propagation and maintenance of a healthy, well balanced population of fish and wildlife. Thus, there is a need to establish the sources of lake water pollution by heavy metals in order to design further strategies limiting the amounts of heavy metals entering Lake Kivu.

\section{Acknowledgments}

The authors would like to thank the scientific committee of the $2^{\text {nd }}$ Springer EMCEI (www.emcei.net) for evaluation of this manuscript. This study was financially supported by the Ordinary Research Grant under the University of Rwanda and Sweden Collaboration.

\section{REFERENCES}

Aderinola OJ, Clarke EO, Olarinmoye OM, Kusemiju V, Anatekhai MA (2009) Heavy metals in surface water, sediments, fish and Perwinklesof Lagos Lagoon. Am.-Eurasian J. Agric. Environ. Sci.5(5):609-617.

Afshan S, Ali S, Ameen US, Farid M, Bharwana SA, Hannan F, Ahmad R (2014) Effect of different heavy metal pollution on fish. Res. J. Chem. Env. Sci. 2(1):74-79.

Aliyu JA, Saleh Y, Kabiru S (2015) Heavy metals pollution on surface water sources in Kaduna metropolis, Nigeria Science World Journal 10(2):1-5.

Al-Najjar T, Al-Momani R, Khalaf M, Wahsha M, Sbaihat M, Khalaf N, Khadra KA, Magames H (2016) Levels of Heavy Metals in Fishes (Cheilinus trilobatus) from the Gulf of Aqaba, Jordan. Natural Science 8(06):256.

Aprile FM, Bouvy M (2010) Heavy metal levels in surface waters from a tropical river basin, Pernambuco State, northeastern Brazil. Acta Scientiarum. Biological Sciences 32(4):357364.https://doi.org/10.4025/actascibiolsci.v32i4.5231

Ashraf MA, Maah MJ, Yusoff I (2012) Bioaccumulation of Heavy Metals in Fish Species Collected From Former Tin Mining Catchment. Int. J. Environ. 6: 209-218.

Baden SP, Eriksson SP (2006) Oceanography and marine biology: an annual review. Role, routes and effects of manganese in crustaceans. Taylor and Francis, London. 2006:61-83.

Bagalwa M, Majaliwa JG, Kansiime F, Bashwira S, Tenywa M, Karume K (2015) Sediment and nutrient loads into river Lwiro, in the Lake Kivu basin, Democratic Republic of Congo.

Int. J. Biol. Chem. Sci. 9(3):1678-1690.https://doi.org/10.4314/ijbcs.v9i3.46

Bagnato E, Tamburello G, Avard G, Martinez-Cruz M, Enrico M, Fu X, Sprovieri M, Sonke JE (2015) Mercury fluxes from volcanic and geothermal sources: an update. Geological Society, London, Special Publications 410(1):263-285.https://doi.org/10.1144/SP410.2

Bärenbold F, Schmid M, Brennwald MS, Kipfer R (2020) Missing atmospheric noble gases in a large tropical lake: The case of Lake Kivu, East-Africa :Chemical Geology 532, 119374.https://doi.org/10.1016/j.chemgeo.2019.119374

Bazimenyera JD, Qiang F, Niragire T (2014) Seasonal Variation of Major Elements in South Lake Cyohoha, Rwanda. Journal of Northeast Agricultural University (English Edition) 21(1):56-63.

Cherif E, Pringault O, Hannaoui W, Yahia MN (2015) Effects of Cadmium Exposure on 
Reproduction and Survival of the Planktonic Copepod Centropages ponticus. J Marine Sci Res Dev 5: 159. https://doi.org/10.4172/2155-9910.100015 9

EPA (2018) Water Quality Standards. US Environmental Protection Agency, 2018.

Deuser WG, Degens ET, Harvey GR, Rubin M (1973) Methane in Lake Kivu: new data bearing on its origin. Science 181(4094): 51-54.

Dsikowitzky L, Mengesha M, Dadebo E, de Carvalho CEV, Sindern S (2013) Assessment of heavy metals in water samples and tissues of edible fish species from Awassa and Koka Rift Valley Lakes, Ethiopia. Environmental monitoring and assessment 185(4): 31173131.

Hansell AL, Horwell CJ, Oppenheimer C (2006) The health hazards of volcanoes and geothermal areas. Occupational and environmental medicine 63(2):149-156. doi:10.1136/oem.2005.022459

He L, Gao B, Luo X, Jiao J, Qin H, Zhang C, Dong Y (2018) Health risk assessment of heavy metals in surface water near a uranium tailing pond in Jiangxi Province, south China. Sustainability 10(4):1113.https://doi.org/10.3390/su10041113

Jamal Q, Durani P, Khan K, Munir S, Hussain S, Munir K, Anees M (2013) Heavy metals accumulation and their toxic effects. Journal of Bio-Molecular Sciences 1(1):27-36.

Jannasch HW (1975) Methane oxidation in Lake Kivu (central Africa) 1. Limnology and Oceanography 20(5):860-864.

Jaishankar M, Tseten T, Anbalagan N, Mathew BB, Beeregowda KN (2014) Toxicity, mechanism and health effects of some heavy metals. Interdisciplinary toxicology 7(2): 60-72.

Kampayana F, Nguyen ST, Le MH (2016) Tilapia cage culture in Rwanda: Current status and prospects for future development. International Journal of Fisheries and Aquatic Studies 4(3):428-435.

Mavura WJ, Wangila PT (2003) The pollution status of Lake Nakuru, Kenya: heavy metals and pesticide residues, 1999/2000. African Journal of Aquatic Science 28(1):13-18.

Mensoor M, Said A (2018) Determination of heavy metals in freshwater fishes of the Tigris River in Baghdad. Fishes 3(2):23. https://doi.org/10.3390/fishes3020023

Mupenzi JD, Ge J, Habiyaremye G (2009) Major Elements in Lake Muhazi, Rwanda, East Africa. Acta Geologica Sinica-English Edition 83(5):927-931.

Muvundja FA, Pasche N, Bugenyi FW, Isumbisho M, Müller B, Namugize JN, Rinta P, Schmid M, Stierli R, Wüest A (2009) Balancing nutrient inputs to Lake Kivu. Journal of Great Lakes Research 35(3):406-418.

Obrist D, Kirk JL, Zhang L, Sunderland EM, Jiskra M, Selin NE (2018) A review of global environmental mercury processes in response to human and natural perturbations: Changes of emissions, climate, and land use. Ambio 47(2):11640.https://doi.org/10.1007/s13280-017-1004-9

Ogwok P, Muyonga JH, Sserunjogi ML (2009) Pesticide residues and heavy metals in Lake Victoria Nile perch, Lates niloticus, belly flap oil. Bulletin of environmental 
contamination and toxicology 82(5):529-533.

Olapade OJ, Omitoyin BO (2012) Anthropogenic pollution impact on physico-chemical characteristics of Lake Kivu, Rwanda. African J. Food Agric. Nutr. Dev. 12(5):65176536.

Pacyna EG, Pacyna JM, Sundseth K, Munthe J, Kindbom K, Wilson S, Steenhuisen F, Maxson P (2010) Global emission of mercury to the atmosphere from anthropogenic sources in 2005 and projections to 2020. Atmospheric Environment 44(20):2487-2499.

Pasche N, Schmid M, Vazquez F, Schubert CJ, Wüest A, Kessler JD, Pack MA, Reeburgh WS, Bürgmann H (2011) Methane sources and sinks in Lake Kivu. Journal of Geophysical Research: Biogeosciences 116(G3).

RAB, 2018. RAB Annual report 2017-2018, Kigali, Rwanda.

Roland FA, Darchambeau F, Morana C, Borges AV (2017) Nitrous oxide and methane seasonal variability in the epilimnion of a large tropical meromictic lake (Lake Kivu, East-Africa). Aquatic sciences 79(2):209-218.

Saha R, Nandi R, Saha B (2011) Sources and toxicity of hexavalent chromium. Journal of Coordination Chemistry 64(10):1782-806.https://doi.org/10.1080/0095972.2011.583646

Sani U (2017) Determination of some heavy metals concentration in the tissues of Tilapia and Catfishes. Biokemistri23(2):73-80.

Schmid M, Wüest A (2012) Stratification, mixing and transport processes in Lake Kivu. In: Descy JP, Darchambeau F, Schmid M (Eds) Lake Kivu: Limnology and biogeochemistry of a tropical great lake. Springer Science \& Business Media, pp. 13-29. Springer, Dordrecht.

Shah AI (2017) Heavy metal impact on aquatic life and human health-an over view. InIAIA17 Conference Proceedings| IA's Contribution in Addressing Climate Change 37th Annual Conference of the International Association for Impact Assessment 2017 Apr (pp. 4-7).

Shehu J, Yusuf YO, Ekwumemgbo AP, Adedapo JO (2015) Dissolved sediment delivery by the Samaru stream into the Ahmadu Bello university reservoir, Zaria, Nigeria. Paper presented in $6^{\text {th }}$ International Conference and Annual General Meeting of Nigeria Association of Hydrological Sciences (NAHS), A.B.U. 15-18/09/2015.

Tchounwou PB, Yedjou CG, Patlolla AK, Sutton DJ (2012) Heavy metal toxicity and the environment. In: Luch A (Ed) Molecular, clinical and environmental toxicology.Springer, Basel, pp. 133-164.https://doi.org/10.1007/978-3-7643-8340-4

Thangam Y, Jayaprakash S, Perumayee M (2014) Effect of copper toxicity on hematological parameters to fresh water fish Cyprinus carpio (common carp). Journal of Environmental Science, Toxicology and Food Technology 8(9):50-60.

Thangamalathi S, Anuradha V (2018) Seasonal Variations In Physico-Chemical Parameters of Seven Different Lakes In Chennai, Tamil Nadu, India.IOSR Journal of Environmental Science, Toxicology and Food Technology 12(9):11-17.

Wang Q, Kim D, Dionysiou DD, Sorial GA, Timberlake D (2004) Sources and remediation for 
mercury contamination in aquatic systems - a literature review. Environmental pollution 131(2):323-336.

Wüest A, Jarc L, Bürgmann H, Pasche N, Schmid M (2012) Methane formation and future extraction in Lake Kivu. In: Descy JP, Darchambeau F, Schmid M (Eds) Lake Kivu: Limnology and biogeochemistry of a tropical great lake. Springer Science \& Business Media, Springer, Dordrecht, pp. 165-180.

Yabe J, Ishizuka M, Umemura T (2010) Current levels of heavy metal pollution in Africa. Journal of Veterinary Medical Science 72(10):1257-1263. 